\title{
Penilaian Tingkat Layak Huni terhadap Aspek Sistem Jaringan Drainase Kecamatan Sungai Kunjang berdasarkan Persepsi Masyarakat
}

\author{
Livability Level Assessment of the Drainage Network System in Sungai \\ Kunjang District Based on Community Perception
}

\author{
Romi Alfianor ${ }^{\mathrm{a}}$, Mega Ulimaz ${ }^{\mathrm{a}}$, Achmad Ghozali ${ }^{\mathrm{a} *}$ \\ ${ }^{a}$ Institut Teknologi Kalimantan, Balikpapan, Indonesia
}

\begin{abstract}
Abstrak
Pada tahun 2017 Kota Samarinda diklasifikasikan oleh Ikatan Ahli Perencanaan (IAP) sebagai kota yang tidak layak huni. Standar rata-rata kota layak huni secara nasional memiliki nilai persentase sebesar 63,2 persen tingkat layak huni, sedangkan Kota Samarinda memiliki nilai lebih rendah dari nilai rata-rata nasional. Kota Samarinda hanya memiliki nilai persentase sebesar 56,9 persen tingkat layak huni sehingga diklasifikasikan sebagai kota yang tidak layak huni dari persepsi masyarakat. Salah satu penilaian kriteria layak huni yang memiliki nilai terendah adalah kondisi sistem jaringan drainase dengan persentase 45 persen tingkat layak huni. Sistem drainase yang ada saat ini belum berfungsi optimal terutama pada kapasitas saluran. Tidak tertampungnya limpasan air hujan pada saluran akan mengakibatkan genangan pada ruas jalan. Salah satunya terdapat pada Jalan Pangeran Antasari Kecamtan Sungai Kunjang. Pada saat musim pasang surut air Sungai Mahakam, ketinggian genangan mencapai sekitar 50-80 cm dengan lama genangan 6-10 jam.
\end{abstract}

Kata kunci:Drainase; Layak Huni; Saluran.

\begin{abstract}
In 2017, Samarinda was classified by the Association of Planning Experts (IAP) as a city that is not livable. The average standard of the national liveable city has a percentage value of 63.2 percent of livable levels. The city of Samarinda has a lower value than the national average value. The city of Samarinda has only a percentage value of 56.9 percent of livable levels, thus classified as a city that is not livable from community perception. One of the assessments of livable criteria that have the lowest value is the condition of a drainage network system with a percentage of 45 percent of liveable levels. The current drainage system has not been functioning optimally especially on the canal capacity. Not accommodating runoff water in the canal will cause inundation on the road section. One of them happened on Jalan Pangeran Antasari, Kecamatan Sungai Kunjang. During the tidal season of the Mahakam River, the height of the inundation reaches about $50-80 \mathrm{~cm}$ with a length of 6-10 hours.
\end{abstract}

Keyword: Canal; Drainage; Livable.

\section{Pendahuluan}

Kota layak huni mengacu pada sistem perkotaan yang berkontribusi terhadap kondisi fisik, sosial, mental, dan pribadi dalam meningkatkan kesejahteraan bagi penghuninya (Sen, 2013).

\footnotetext{
* Corresponding author.Romi Alfianor

E-mail address:08161072@student.itk.ac.id.
} 
Selain itu, kota layak huni adalah sebuah tempat bagi seluruh penduduk kota yang memiliki tata kelola lingkungan dalam menyediakan jaringan infrastruktur kota yang terdiri dari pelayanan, fasilitas, utilitas, perumahan yang terjangkau, pekerjaan, taman, ruang terbuka hijau (Elshater, 2016). Konsep kota layak huni juga dapat diartikan sebagai gambaran proses kehidupan menuju kesejahteraan dan kenyamanan masyarakat kota dalam mengakses fasilitas pelayanan kota (Makakalag, 2019).

Pada tahun 2017 IAP (Ikatan Ahli Perencanaan) Indonesia merilis Most Livable City Index di Indonesia, berdasarkan persepsi masyarakat, Kota Samarinda memiliki persentase sebesar 56,9 persen tingkat layak huni. Hal ini mengakibatkan Kota Samarinda dikatekorikan sebagai kota tidak layak huni karena memiliki nilai persentase dibawah dari nilai rata - rata nasional kota layak huni dengan persentase sebesar 63,2 persen tingkat layak huni. Pada masing - masing kriteria, hasil penilaian kriteria layak huni yang memiliki nilai terendah di Kota Samarinda meliputi fasilitas pejalan kaki dengan persentase 39\% layak huni, infomasi pembangunan dan partisipasi masyarakat dengan persentase 34\% layak huni, fasilitas kesenian dan budaya dengan persentase 49\% layak huni, kondisi jaringan drainase dengan persentase $45 \%$ layak huni, serta keselamatan kota dengan persentase 34\% layak huni (MLCI, 2017).

Sistem drainase Kota Samarinda saat ini masih belum sesuai dengan standar sistem drainase kota yang baik dan beberapa saluran sudah mengalami kerusakan. permasalahan banjir yang terjadi di Kecamatan Sungai Kunjang disebabkan adanya luapan air yang tidak mampu tertampung pada daerah hulu, sehingga aliran air bergerak menuju wilayah yang lebih rendah, satunya terjadi pada Jalan Pangeran Antasari yang menjadi langganan banjir setiap turunnya hujan. Selain itu, kenaikan muka air Sungai Mahakam akan menyebabkan tampungan air Sungai Loa Buah meluap dan menggenangi daerah disekitar sungai dengan ketinggian sekitar 50-80 cm dan lama genangan bisa mencapai 6-10 jam (Purwanto, 2016).

Dalam upaya membantu pemerintah untuk menangani permasalahan banjir tersebut diperlukan pembahasan lebih lanjut terkait pengaruh sistem jaringan drainase terhadap kelayakhunian bagi masyarakat Kota Samarinda khususnya di Kecamatan Sungai Kunjang.

\section{Metode}

Teknik analisis data yang digunakan adalah analisis deskriptif kualitatif menggunakan penilaian skala linkert. Skala linkert digunakan untuk mengukur persepsi masyarakat terhadap penelitian tingkat layak huni jaringan drainase. Dalam penelitian ini analisis skala linkert dilakukan melalui penyebaran kuesioner kepada masing-masing sampel yang telah ditentukan. Bentuk pertanyaan kuesioner dibuat dalam pernyataan positif untuk lebih jelasnya dapat dilihat pada Lampiran B. Pada kuesioner yang akan dibuat memiliki 5 opsi jawaban dengan masingmasing skoring yang telah ditentukan yaitu:

1. Responden sangat setuju yang diberi kode (SS) yang berarti sangat setuju terhadap pernyataan dari peneliti memiliki bobot 5 ;

2. Responden setuju yang diberi kode (S) yang berarti setuju terhadap pernyataan dari peneliti memiliki bobot 4;

3. Responden netral yang diberi kode $(\mathrm{N})$ berarti responden merasa setuju namun juga tidak setuju terhadap pernyataan dari peneliti memiliki bobot 3;

4. Responden tidak setuju yang diberi kode (TS) berarti tidak setuju terhadap pernyataan dari peneliti memiliki skor 2;

5. Responden tidak setuju yang diberi kode (STS) berarti sangat tidak setuju terhadap pernyataan dari peneliti memiliki skor 1 .

Setelah mendapatkan jawaban persepsi masyarakat terkait dengan kelayakhunian Kota Samarinda, kemudian dilakukan rekapitulasi seluruh jawaban responden. Selanjutnya, dilakukan uji validitas digunakan untuk mengukur sah/valid atau tidaknya butir pertanyaan yang terdapat dalam kuesioner. Kuesioner dikatan valid jika butir pertanyaan kuesioner mampu untuk menjelaskan kondisi sebenarnya yang akan diukur dan uji realibilitas agar jawaban responden yang diberikan dapat dipercaya keaslian fakta yang diberikan. Dalam penelitian ini uji validitas dan uji reliabilitas digunakan menggunakan aplikasi SPSS adapun standar masing-masing uji Menurut Sugiyono (2013) adalah.

1. Uji validitas 
Dilakukan dengan membandingkan $r$ hitung dan $r$ tabel. Jika $r$ hitung $>r$ tabel maka dapat dikatakan valid, sebaliknya jika $r$ hitung $<r$ tabel maka tidak valid. Standar $r$ tabel adalah 0,3 .

2. Uji Reliabilitas

Dilakukan dengan membandingkan angka cronbach alpha dengan ketentuan minimal angka cronbach alpha sebesar 0,6 . Jika hasil perihitungan cronbach alpha > standar maka dapat dikatakan reliabel, sebaliknya jika perhitungan crinbach alpha $<$ standar maka tidak reliabel.

Ketika hasil kuiesioner menyatakan valid dan reliabel terhadap jawaban responden dapat dilakukan pengolahan data dengan mencari nilai rata-rata dari total skoring tingkat layak huni sistem jaringan drainase untuk menentukan kelayakhunian masing-masing wilayah RT sesuai dengan jawaban responden, sehingga didapatkan tipologi layak huni dengan kriteria jika diatas nilai tingkat layak huni berada di atas nilai rata-rata tingkat layak huni secara keselurahan, maka dikatakan wilayah tersebut layak huni. Sebaliknya, jika berada dibawah nilai rata rata tingkat layak huni, maka dikatakan wilayah tersebut tidak layak huni.

\section{Sistem Drainase Perkotaan yang Layak}

Menteri Pekerjaan Umum dalam Permen PU Nomor 12 Tahun 2014 menyebutkan bahwa konsep sistem jaringan drainase perkotaan saat ini mengacu pada munculnya paradigma baru yaitu ekodrainase atau drainase yang ramah lingkungan, dalam pengertiannya ekodrainase merupakan upaya meresapkan limpasan air hujan kedalam tanah secara alamiah atau mengalirkan air pada tampungan buatan atau badan air alamiah untuk dapat dimanfaatkan. Fairizi (2015) juga berpandangan sistem jaringan drainase harus mampu mengurangi kelebihan tampung air pada sistem drainase yang berasal dari air hujan, rembesan, dan kelebihan air irigasi. Dengan adanya konsep sistem jaringan drainase yang berwawasan lingkungan diharapkan kejadian genangan air tidak menyebabkan banjir karena tampungan air yang terdapat pada drainase telah dikurangi debit airnya melalui tempat penampungan air buatan dan meresapkan kedalam lapisan tanah.

Pembentukan sistem jaringan drainase perkotaan Menurut Maizir (2017) terbagi kedalam 2 jenis sistem drainase yaitu drainase utama dan drainase pengumpul. Sistem jaringan utama adalah saluran primer dan sekunder, secara operasional sistem jaringan utama bekerja untuk penampungan seluruh aliran buangan dari saluran primer dan saluran pengumpul menuju saluran primer yang kemudian dialirkan pada sungai, danau, atau laut sebagai tempat pembuangan akhir. Disamping itu, sistem jaringan pengumpul adalah saluran tersier yang berperan sebagai penampung aliran buangan rumah tangga yang akan dialirkan menuju saluran sekunder dan primer.

Dalam mencapai sistem drainase perkotaan yang layak, menurut Riman (2011) hal yang perlu diperhatikan adalah permasalahan drainase perkotaan yang terjadi akibat gangguan manusia dan akibat gangguan alam. Beragamnya kegiatan manusia dapat menimbulkan hambatan kelancaran pengaliran buangan limpasan air hujan yang terjadi karena adanya perubahan tata guna lahan, perubahan fungsi saluran drainase, pembuangan sampah kedalam saluran drainase, adanya kawasan kumuh, dan tidak berfungsinya saluran drainase akibat adanya kerusakan. Disisi lain, gangguan yang disebabkan oleh alam dipengaruhi karena adanya erosi, sedimentasi, curah hujan, dan pasang surut air laut. Selain itu, drainase yang layak juga perlu memperhatikan faktor yang dapat menyebabkan terjadinya kegagalan operasional drainase menurut Maizir (2017) tergolong kedalam 6 faktor utama yaitu:

1. Kerusakan lingkungan dipengaruhi adanya konversi lahan menjadi lahan terbangun yang memiliki perkerasan mengurangi daya serap tanah dan persentase ruang terbuka hijau yang semakin berkurang.

2. Sistem drainase dipengaruhi dimensi saluran yang terlalu kecil akan mengakibatkan timbulnya genangan.

3. Pertimbangan kajian perencanaan dipengaruhi kondisi kepadatan lingkungan permukiman, topografi, jenis air buangan, besaran intensitas hujan, koefisien limpasan air, dan luas daerah tangkapan aliran.

4. Masalah sampah dipengaruhi panjang saluran drainase yang terhambat sampah.

5. Kesalahan dalam pembangunan drainase dipengaruhi kesalahan konstruksi yang tidak 
dengan sesuai dengan standar operasional.

6. Partisipasi masyarakat dipengaruhi peran serta masyarakat dalam menjaga dan memilihara kebersihan drainase.

Disisi lain, Deliana (2017) tingkat keberhasilan implementasi drainase yang layak perlu memperhatikan faktor-faktor yang dapat mempengaruhi diantaranya kinerja sistem drainase dan kinerja bangunan drainase. Secara lebih spesifik kinerja sistem drainase dan kinerja bangunan drainase memiliki indikator penentu Kinerja sistem drainase dengan (1) Kepahaman mengenai karakteristik permasalahan drainase; (2) Kepahaman mengenai kebijakan dan peraturan drainase; (3) Adanya komitmen dalam menjaga lingkungan implementasi; (4) Kesesuaian perencanaan sistem drainase; (5) Terdapatnya prosedur pengelolaan sistem drainase: (6) Ketersediaan pengelola sistem drainase; (7) Frekuensi evaluasi sistem drainase; (8) Ketersediaan bangunan drainase dan fasilitas pelengkapnya; (9) Frekuensi pemeliharan bangunan drainase. Kemudian kinerja bangunan memiliki indikator (1) Kelancaran sistem drainase; dan (2) Tersediannya anggaran biaya pemeliharaan.

Hasil identifikasi prioritas permasalahan sistem drainase menurut Helfira dkk (2013) penentuan parameter terbagi dalam beberapa kriteria (1) Kriteria teknis yang terdiri dari Kondisi fisik dan fungsi drainase, Kapasitas jaringan drainase, Kondisi infrastruktur jalan, Karakteristik genangan air, Kesesuaian drainase jalan, Koordinasi dinas terkait, Perubahan tata guna lahan. (2) Kriteria ekonomi terdiri dari biaya pekerjaan pembangunan sistem drainase, ketersediaan dana untuk pembiayaan operasional dan pemeliharaan tahunan sistem drainase dan biaya evaluasi monitoring tahunan sistem drainase. (3) Kriteria lingkungan dengan memperhatikan kepadatan lalu lintas, kesehatan lingkungan, luas daerah layanan, volume sampah, pencemaran air permukaan. (4) Kriteria sosial/budaya berupa kepedulian dan keterlibatan masyarakat, pengelolaan dan pemeliharaan prasarana drainase, perilaku masyarakat, dan berkurangnya produktivitas kerja

Berdasarkan pemaparan masing-masing pendapat yang telah disampaikan oleh para ahli berkaitan dengan sistem drainase yang layak, Dari penjelasan yang telah disampaikan oleh Riman (2011), Deliana (2017), Maizir (2017), dan Helfira dkk (2013) masing-masing memiliki keterhubungan satu sama lain untuk mencapai sistem drainase perkotaan yan layak. Jika dibandingkan dengan tujuan penelitian, maka variabel yang seusai dalam konteks penelitian yang akan dipilih meliputi peran serta masyarakat dalam menjaga kebersihan saluran, frekuensi pemeliharaan bangunan drainase, kapasitas jaringan drainase, karakteristik genangan air, koordinasi dengan dinas terkait, perubahan tata guna lahan, pencemaran air permukaan.

\section{Hasil dan Pembahasan}

Ruang lingkup penelitian ini meliputi wilayah Kecamatan Sungai Kunjang yang terdiri dari 7 Kelurahan dan wilayah RT yang dilewati oleh saluran drainase primer dan sekunder memiliki jumlah total 197 RT. Persebaran jumlah RT pada setiap kelurahan yaitu Kelurahan Karang Anyar sebanyak 29 RT, Karang Asam Ilir sebanyak 21 RT, Karang Asam Ulu sebanyak 29 RT, Loa Bakung sebanyak 57 RT, Loa Buah sebanyak 8 RT, Lok Bahu sebanyak 22 RT, dan Teluk Lerong Ulu sebanyak 31 RT. Dari total 197 RT yang diteliti ditetapkan masing-masing wilayah RT diambil sampel menggunakan kouta 5 orang pada setiap RT, sehingga total responden berjumlah 985 orang.

Dalam penilaian tingkat layak huni pengambilan data dilakukan menggunakan kuesioner skala linkert. Dari total 7 variabel dalam penilaian tingkat layak huni berdasarkan aspek sistem jaringan drainase, setiap variabel ditransformasikan kedalam bentuk pernyataan kuesioner. Jumlah pernyataan yang ditanyakan kepada masyarakat yaitu sebanyak 21 pernyataan yang terdiri dari 3 pernyataan dari setiap variabel yang digunakan. Sebelum pengolahan data kuesioner, terlebih dahulu dilakukan pengecekan hasil jawaban seluruh responden untuk menilai tingkat validitas dan reliabilitas jawaban responden yang dilakukan adapaun hasil dari analisis tingkat validitas dan reliabilitas adalah sebagai berikut. 
Tabel 1. Hasil Validitas Setiap Pernyataan (Penulis,2020)

\begin{tabular}{|c|c|c|}
\hline No. & Pernyataan & $\begin{array}{c}\text { Nilai } \\
\text { Korelasi }\end{array}$ \\
\hline 1 & Kebersihan saluran drainase adalah tanggung jawab masyarakat & 0,430 \\
\hline 2 & $\begin{array}{l}\text { Saya akan langsung menegur jika melihat orang yang buang sampah di saluran } \\
\text { drainase }\end{array}$ & 0,483 \\
\hline 3 & Saya bergerak untuk membersihkan saluran jika saya menemui sumbatan & 0,512 \\
\hline 4 & $\begin{array}{l}\text { Saya rutin mengeruk pasir yang terdapat pada saluran drainase setiap satu bulan } \\
\text { sekali }\end{array}$ & 0,502 \\
\hline 5 & $\begin{array}{l}\text { Kegiatan kerja bakti pembersihan saluran drainase sebaiknya rutin dilakukan } \\
\text { setiap dua kali dalam sebulan }\end{array}$ & 0,493 \\
\hline 6 & $\begin{array}{l}\text { Perbaikan dan peningkatan kualitas drainase dari sisi bangunan saluran dan } \\
\text { kapasitas selalu dilakukan setiap tahun sekali }\end{array}$ & 0,491 \\
\hline 7 & $\begin{array}{l}\text { Menurut saya saluran drainase di lingkungan ini sudah sesuai dengan standar } \\
\text { yang ada }\end{array}$ & 0,631 \\
\hline 8 & saluran drainase sekitar lingkungan saya dapat menampung dengan baik & 0,639 \\
\hline 9 & $\begin{array}{l}\text { Saya merasa air hujan yang turun selalu lancar mengalir pada saluran drainase } \\
\text { yang ada }\end{array}$ & 0,700 \\
\hline 10 & $\begin{array}{l}\text { Saluran yang ada di lingkungan saya sudah cukup untuk menanpung limpasan air } \\
\text { hujan sehingga tidak menimbulkan genangan yang lama }\end{array}$ & 0,712 \\
\hline 11 & $\begin{array}{l}\text { Di lingkungan saya sesekali terdapat genangan, tetapi tidak sampai menghambat } \\
\text { aktivitas sehari-hari }\end{array}$ & 0,597 \\
\hline 12 & Genangan air selalu dapat diatasi dalam waktu yang singkat & 0,626 \\
\hline 13 & $\begin{array}{l}\text { Pemerintah selalu merespons dengan cepat untuk menangani genangan yang } \\
\text { terjadi }\end{array}$ & 0,563 \\
\hline 14 & $\begin{array}{l}\text { Perangkat pemerintah selalu mengajak untuk menjaga dan membersihkan saluran } \\
\text { drainase dari sampah }\end{array}$ & 0,583 \\
\hline 15 & $\begin{array}{l}\text { Setiap tahun pemerintah selalu memiliki program perbaikan dan peningkatan } \\
\text { kualitas drainase }\end{array}$ & 0,550 \\
\hline 16 & $\begin{array}{l}\text { Lingkungan saya sudah mendapatkan distribusi ruang terbuka yang cukup } \\
\text { sebagai tempat peresapan air }\end{array}$ & 0,562 \\
\hline 17 & $\begin{array}{l}\text { Saya merasa pemerintah sudah baik dalam menjalankan rencana tata ruang } \\
\text { terutama untuk mereduksi resiko bencana banjir }\end{array}$ & 0,609 \\
\hline 18 & $\begin{array}{l}\text { Menurut saya rencana tata ruang Kota Samarinda sudah cukup baik untuk } \\
\text { mengurangi kejadian bencana banjir }\end{array}$ & 0,616 \\
\hline 19 & $\begin{array}{l}\text { Saya merasa saluran drainase yang ada ini belum tercemar oleh limbah sehingga } \\
\text { tidak berwarna hitam }\end{array}$ & 0,519 \\
\hline 20 & $\begin{array}{l}\text { Saya merasa saluran drainase yang ada disekitar tidak menimbulkan bau yang } \\
\text { menyengat }\end{array}$ & 0,546 \\
\hline 21 & $\begin{array}{l}\text { Saya merasa aliran air yang terhambat bukan disebabkan karena banyaknya } \\
\text { sedimentasi pada saluran drainase }\end{array}$ & 0,571 \\
\hline \multicolumn{3}{|c|}{$\begin{array}{l}\text { Dari tabel diatas dapat diketahui bahwa seluruh pernyataan memiliki nilai korelasi lebih } \\
\text { dari standar } 0,3 \text { sehingga dapat dikatakan jawaban yang diberikan oleh responden adalah } \\
\text { Sementara untuk perhitungan reliabilitas didaptkan angka angka cronbach alpha sebesar } \\
7 \text { lebih besar dari standar } 0,6 \text {. Maka seluruh jawaban responden dapat dilakukan pengolahan } \\
\text { lebih lanjut untuk menentukan nilai tingkat layak huni pada masing-masing RT. }\end{array}$} \\
\hline
\end{tabular}


Tabel 2. Data Frekuensi Rata-Rata Persepsi Masyarkat Berdasarkan Variabel Penilaian Kelayakhunain Drainase Kecamatan Sungai Kunjang (Penulis, 2020)

\begin{tabular}{|c|c|c|c|c|c|c|c|c|c|c|}
\hline \multirow{2}{*}{ Variabel } & \multicolumn{2}{|c|}{ SS } & \multicolumn{2}{|c|}{$\mathbf{S}$} & \multicolumn{2}{|c|}{$\mathbf{N}$} & \multicolumn{2}{|c|}{ TS } & \multicolumn{2}{|c|}{ STS } \\
\hline & $\mathbf{F}$ & $\%$ & $\mathbf{F}$ & $\%$ & $\mathbf{F}$ & $\%$ & $\mathbf{F}$ & $\%$ & $\mathbf{F}$ & $\%$ \\
\hline $\begin{array}{l}\text { Peran serta masyarakat dalam menjaga } \\
\text { kebersihan saluran }\end{array}$ & 16 & 2 & 435 & 44 & 360 & 36 & 173 & 18 & 1 & 0 \\
\hline Frekuensi pemeliharaan sistem drainase. & 8 & 1 & 290 & 29 & 393 & 40 & 291 & 30 & 3 & 0 \\
\hline Kapasitas jaringan drainase & 4 & 0 & 532 & 54 & 222 & 23 & 215 & 22 & 12 & 1 \\
\hline Karakteristik genangan air & 12 & 1 & 562 & 57 & 189 & 19 & 192 & 20 & 30 & 3 \\
\hline Koordinasi dengan dinas terkait & 0 & 0 & 201 & 20 & 362 & 37 & 408 & 42 & 14 & 1 \\
\hline Perubahan tata guna lahan & 1 & 0 & 388 & 40 & 344 & 35 & 249 & 25 & 3 & 0 \\
\hline Pencemaran air permukaan & 4 & 0 & 382 & 39 & 259 & 26 & 332 & 34 & 8 & 1 \\
\hline
\end{tabular}

Dari tabel diatas dapat diketahui bahwa variabel peran serta masyarakat memiliki rata-rata jawaban responden setuju sebanyak 435 orang. Variabel frekuensi pemeliharaan saluran memiliki rata-rata jawaban responden netral sebanyak 360 orang. Variabel kapasitas saluran memiliki ratarata jawaban responden setuju sebanyak 532 orang. Variabel karakteristik genangan saluran memiliki rata-rata jawaban responden setuju sebanyak 562 orang. Variabel koordinasi dengan dinas terkait memiliki rata-rata jawaban responden tidak setuju sebanyak 408 orang. Variabel perubahan tata guna lahan memiliki rata-rata jawaban responden setuju sebanyak 388 orang. variabel pencemaran air permukaan memiliki rata-rata jawaban responden setuju sebanyak 382 orang.

Berdasarkan data yang telah disampaikan, maka masyarakat Kecamatan Sungai Kunjang pada wilayah RT yang dilewati saluran drainase menyatakan setuju pada variabel peran serta masyarakat, kapasitas saluran, karakteristik genangan, perubahan tata guna lahan, dan pencemaran air permukaan sehingga pada wilayah masyarakat cenderung sudah layak huni. Sementara itu, pada variabel frekuensi pemeliharaan saluran masyarakat menyatakan netral. Sedangkan, variabel koordinasi dengan dinas terkait masyarakat menyatakan tidak setuju bahwa koordinasi dengan dinas saat ini sudah layak huni. Data persepsi masyarkat akan digunakan untuk melakukan analisis tingkat layak huni dari aspek kondisi saluran drainase. Berikut ini merupakan hasil analisis deskriptif kuantitatif persepsi masyarakat pada setiap variabel penilaian tingkat layak huni.

Tabel 3. Nilai Rata-Rata Setiap Variabel yang digunakan untuk Mengukur Tingkat Layak Luni (Penulis, 2020)

\begin{tabular}{lrrr}
\hline \multicolumn{1}{c}{ Variabel } & $\begin{array}{c}\text { Nilai rata- } \\
\text { rata (\%) }\end{array}$ & $\begin{array}{c}\text { Jumlah RT yang } \\
\text { Tidak Layak }\end{array}$ & $\begin{array}{c}\text { Jumlah RT } \\
\text { yang Layak }\end{array}$ \\
\hline Peran Serta Masyarakat Dalam Menjaga & 65,92 & 97 & 100 \\
Kebersihan Saluran & 60,22 & 112 & 85 \\
Frekuensi Pemeliharaan Sistem Drainase. & 60,08 & 50 & 147 \\
Kapasitas Jaringan Drainase & 66,83 & 69 & 128 \\
Karakteristik Genangan Air & 55,26 & 103 & 94 \\
Koordinasi Dengan Dinas Terkait & 62,70 & 107 & 90 \\
Perubahan Tata Guna Lahan & 60,81 & 86 & 111 \\
Pencemaran Air Permukaan & $\mathbf{6 2 , 0 3}$ & $\mathbf{8 0}$ & $\mathbf{1 1 7}$ \\
Layak Huni & & &
\end{tabular}

Berdasarkan tabel diatas dapat diketahui bahwa nilai rata-rata tingkat layak huni kondisi drainase Kecamatan Sungai Kunjang adalah 62,03\%. Sehingga nilai rata-rata wilayah RT yang berada di bawah dari nilai rata-rata tersebut diklasifikasikan tidak layak huni dan layak huni jika berada diatas nilai rata-rata kecamatan.Variabel frekuensi pemeliharaan saluran, kapasitas drainase, pencemaran air permukaan, dan koordinasi dinas terkait perlu menjadi perhatian bagi pemerintah daerah karena memiliki nilai rata-rata yang berada dibawah dari nilai rata-rata layak huni. Hal ini dimaksudkan agar dapat meningkatkan kelayakhunian kondisi saluran drainase di Kecmatan Sungai Kunjang.

Variabel koordinasi dengan dinas terkait merupakan variabel yang memiliki penilaian 
terendah dengan nilai rata-rata 55,26\%. Pada wilayah studi, masyarakat merasa peran pemerintah masih kurang dalam menanggapi adanya kerusakan pada saluran drainase. Koordinasi dinas lintas sektoral untuk segera memperbaiki dan membersihkan saluran drainase yang mengalami kerusakan atau terhambat sedimen terkesan lambat dan kurang tanggap.

Menurut masyarakat, kondisi genangan air pada ruas jalan akibat tidak tertampungnya limpasan air hujan pada sistem drainase tidak terlalu mempengaruhi kegiatan sehari-hari. Masyarakat cukup puas terhadap variabel karakteristik genangan air memiliki penilaian tertinggi dengan nilai rata-rata $66,83 \%$. Hal ini membuktikan bahwa masyarakat sudah pasrah dan tidak peduli dengan kondisi genangan, karena pada kondisi eksisting tinggi genangan mecapai 50-80 $\mathrm{cm}$ dengan lama genangan 6-10 jam di Kecamatan Sungai Kunjang. Berikut merupakan hasil analisis tingkat layak huni untuk masing-masing wilayah RT.

Tabel 4. Hasil Analisis Tingkat Layak Huni pada Setiap RT (Penulis, 2020)

\begin{tabular}{|c|c|c|c|c|c|c|}
\hline Kelurahan & RT & $\begin{array}{c}\text { Nilai Rata-Rata } \\
(\%)\end{array}$ & RT & $\begin{array}{c}\text { Nilai Rata-Rata } \\
(\%)\end{array}$ & RT & $\begin{array}{c}\text { Nilai Rata-Rata } \\
(\%)\end{array}$ \\
\hline \multirow{10}{*}{ Karang Anyar } & 1 & 63,24 & 14 & 63,24 & 27 & 64,76 \\
\hline & 2 & 68,57 & 15 & 62,09 & 29 & 62,47 \\
\hline & 3 & 60,38 & 16 & 64,95 & 30 & 64,76 \\
\hline & 5 & 63,05 & 17 & 67,62 & 31 & 64,38 \\
\hline & 6 & 70,29 & 20 & 61,71 & 32 & 65,90 \\
\hline & 7 & 61,90 & 21 & 64,95 & 33 & 66,67 \\
\hline & 8 & 59,24 & 23 & 67,81 & 34 & 63,24 \\
\hline & 10 & 62,67 & 24 & 67,43 & 35 & 64,00 \\
\hline & 12 & 63,62 & 25 & 66,10 & 37 & 63,24 \\
\hline & 13 & 61,33 & 26 & 64,57 & & \\
\hline \multirow{7}{*}{$\begin{array}{l}\text { Karang Asam } \\
\text { Ilir }\end{array}$} & 1 & 71,43 & 9 & 64,00 & 24 & 61,71 \\
\hline & 2 & 67,62 & 10 & 65,71 & 28 & 62,29 \\
\hline & 3 & 66,10 & 11 & 62,47 & 29 & 60,00 \\
\hline & 4 & 65,71 & 12 & 66,67 & 31 & 64,19 \\
\hline & 6 & 63,24 & 14 & 65,71 & 33 & 63,43 \\
\hline & 7 & 61,33 & 18 & 68,95 & 34 & 58,10 \\
\hline & 8 & 66,29 & 19 & 65,53 & 35 & 62,09 \\
\hline \multirow{10}{*}{$\begin{array}{c}\text { Karang Asam } \\
\text { Ulu }\end{array}$} & 1 & 61,68 & 19 & 63,24 & 33 & 60,19 \\
\hline & 5 & 60,19 & 20 & 60,57 & 34 & 65,90 \\
\hline & 6 & 60,00 & 22 & 65,71 & 35 & 57,71 \\
\hline & 7 & 59,62 & 23 & 65,53 & 36 & 68,19 \\
\hline & 8 & 61,14 & 25 & 53,90 & 37 & 73,71 \\
\hline & 9 & 61,90 & 27 & 61,53 & 38 & 74,47 \\
\hline & 10 & 64,19 & 29 & 57,53 & 39 & 62,10 \\
\hline & 11 & 63,62 & 30 & 60,95 & 40 & 66,10 \\
\hline & 12 & 61,90 & 31 & 52,95 & 41 & 63,61 \\
\hline & 18 & 61,14 & 32 & 57,53 & & \\
\hline \multirow{17}{*}{ Loa Bakung } & 1 & 68,13 & 25 & 62,86 & 55 & 54,86 \\
\hline & 2 & 63,38 & 29 & 47,24 & 56 & 72,95 \\
\hline & 3 & 66,01 & 33 & 70,47 & 59 & 64,38 \\
\hline & 4 & 64,91 & 34 & 60,38 & 60 & 58,86 \\
\hline & 5 & 66,27 & 35 & 70,67 & 61 & 73,90 \\
\hline & 7 & 56,97 & 36 & 66,86 & 63 & 60,19 \\
\hline & 8 & 55,20 & 37 & 64,38 & 65 & 65,90 \\
\hline & 9 & 52,47 & 39 & 69,33 & 66 & 63,43 \\
\hline & 10 & 50,07 & 40 & 69,14 & 68 & 57,53 \\
\hline & 11 & 62,79 & 42 & 62.67 & 69 & 60,00 \\
\hline & 12 & 64,96 & 43 & 64,57 & 70 & 64,00 \\
\hline & 13 & 68,98 & 44 & 65,71 & 72 & 73,13 \\
\hline & 15 & 60,00 & 45 & 64,76 & 73 & 59,43 \\
\hline & 16 & 65,33 & 46 & 65,33 & 76 & 55,62 \\
\hline & 19 & 52,95 & 47 & 61,52 & 77 & 66,67 \\
\hline & 20 & 49,33 & 48 & 57,71 & 79 & 60,76 \\
\hline & 22 & 53,71 & 49 & 65,52 & 81 & 72,24 \\
\hline
\end{tabular}




\begin{tabular}{ccccccc}
\hline Kelurahan & RT & $\begin{array}{c}\text { Nilai Rata-Rata } \\
(\mathbf{\%})\end{array}$ & RT & $\begin{array}{c}\text { Nilai Rata-Rata } \\
(\mathbf{\%})\end{array}$ & RT & $\begin{array}{c}\text { Nilai Rata-Rata } \\
(\boldsymbol{\%})\end{array}$ \\
\hline \multirow{6}{*}{ Loa Buah } & 23 & 60,19 & 53 & 65,33 & 82 & 69,71 \\
& 24 & 59,81 & 54 & 59,81 & 83 & 54,10 \\
\hline \multirow{6}{*}{ Lok Bahu } & 1 & 59,04 & 8 & 56,38 & 17 & 57,52 \\
& 2 & 54,47 & 9 & 57,81 & 20 & 48,19 \\
& 4 & 51,43 & 10 & 49,71 & & \\
\hline & 1 & 68,76 & 13 & 62,86 & 29 & 66,86 \\
& 2 & 65,90 & 14 & 53,53 & 34 & 54,86 \\
& 3 & 65,33 & 15 & 56,38 & 35 & 64,00 \\
& 5 & 59,62 & 16 & 54,10 & 36 & 62,10 \\
& 6 & 66,10 & 22 & 58,86 & 38 & 52,00 \\
& 10 & 52,76 & 27 & 58,67 & 45 & 63,05 \\
Teluk Lerong & 63,43 & 28 & 62,09 & 48 & 64,00 \\
Ulu & 12 & 61,14 & & & & \\
& 1 & 54,10 & 15 & 68,18 & 27 & 60,57 \\
& 2 & 64,00 & 16 & 62,29 & 28 & 57,90 \\
& 3 & 54,10 & 18 & 61,90 & 29 & 61,33 \\
& 5 & 65,14 & 19 & 63,62 & 31 & 61,71 \\
& 7 & 62,10 & 20 & 67,24 & 32 & 60,00 \\
& 8 & 63,81 & 21 & 70,29 & 33 & 60,29 \\
& 9 & 61,53 & 22 & 70,47 & 39 & 63,05 \\
& 12 & 60,38 & 23 & 69,14 & 40 & 69,14 \\
& 67,43 & 24 & 54,86 & 41 & 69,90 \\
& 13 & 67,24 & 26 & 52,19 & 42 & 68,00 \\
\hline
\end{tabular}

Berdasarkan tabel diatas dapat diketahui bahwa standar tingkat layak huni sistem jaringan drainase Kecamatan Sungai Kunjang adalah $62,03 \%$ yang didapatkan dari hasil rata-rata total nilai skoring variabel penelitian, sehingga dapat diketahui jumlah wilayah RT yang memiliki sistem jaringan drainase layak huni berjumlah 117 RT karena memiliki nilai lebih tinggi dari ratarata Kecamatan. Sisanya sebanyak 80 RT diklasifikasikan sebagai wilayah RT dengan sistem jaringan drainase belum layak karena memiliki nilai lebih rendah dari rata-rata Kecamatan. Berikut ini tampilan peta tingkat layak huni setiap RT pada masing-masing wilayah Kelurahan yang diidentifikasi.
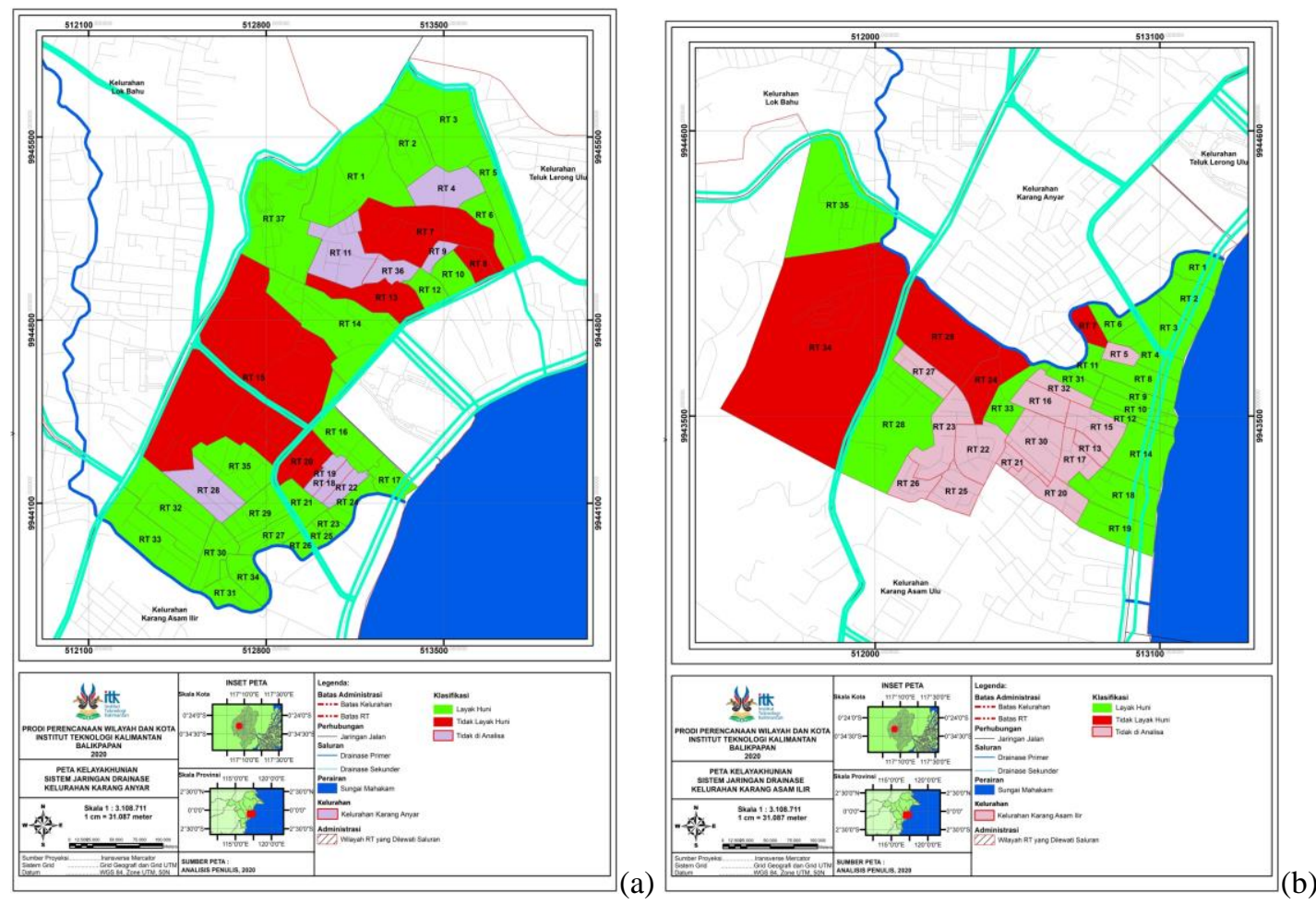

Gambar 1. (a) Tingkat Layak Huni Kelurahan Karang Anyar; (b) Karang Asam Ilir. (Penulis, 2020) 

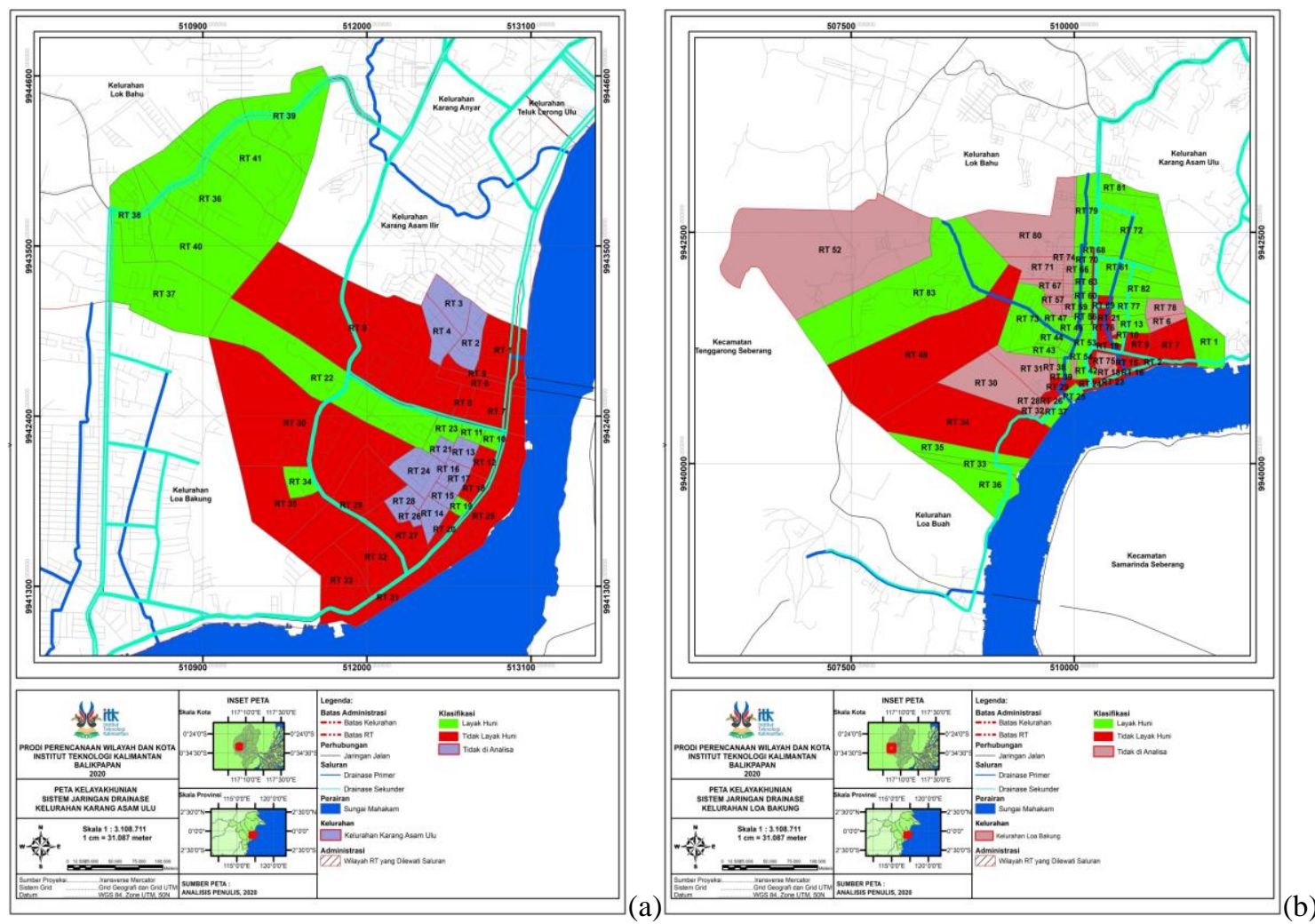

Gambar 2. (a) Tingkat Layak Huni Kelurahan Karang Asam Ulu; (b) Loa Bakung. (Penulis, 2020)
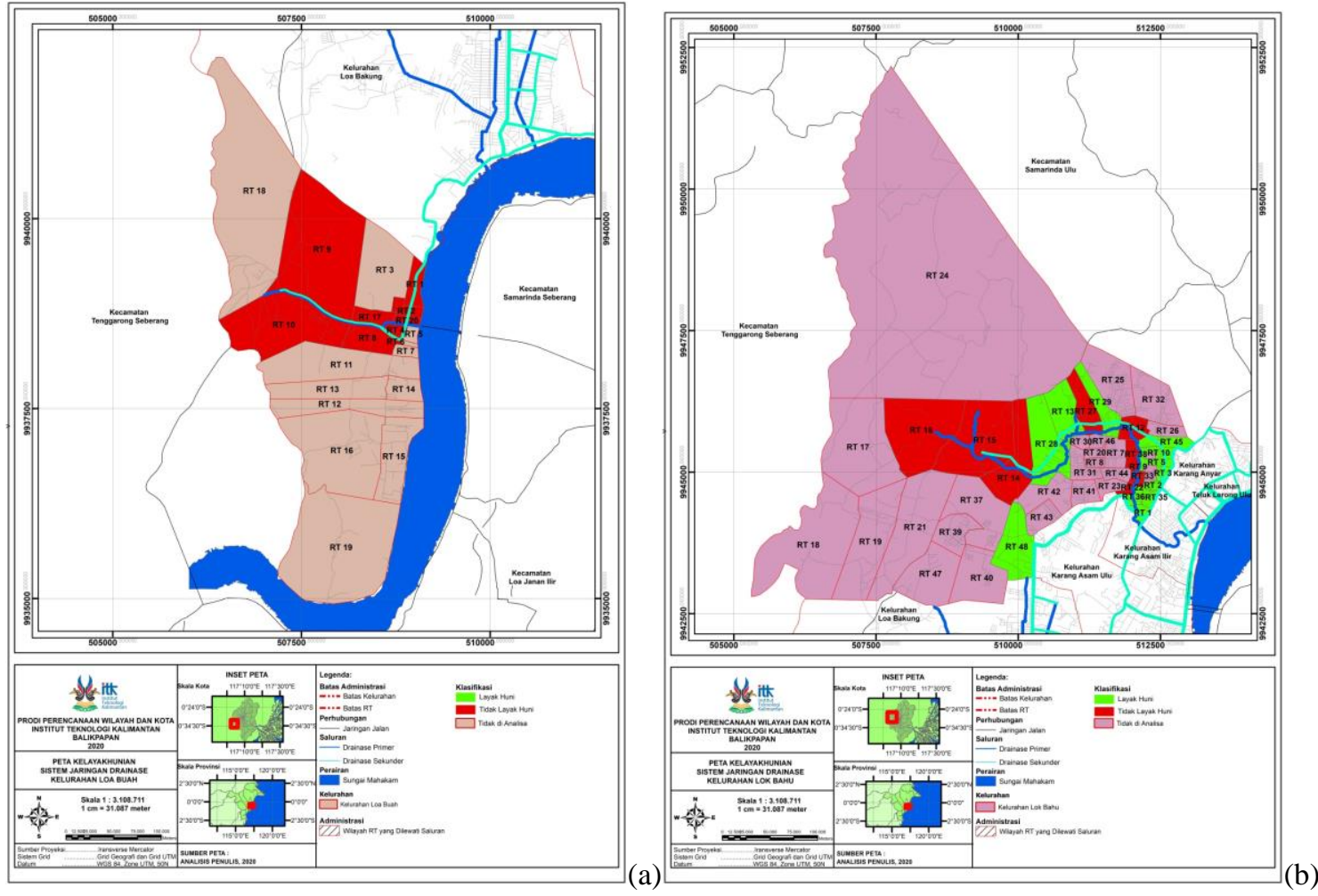

Gambar 3. (a) Tingkat Layak Huni Kelurahan Loa Buah; (b) Lok Bahu. (Penulis, 2020) 


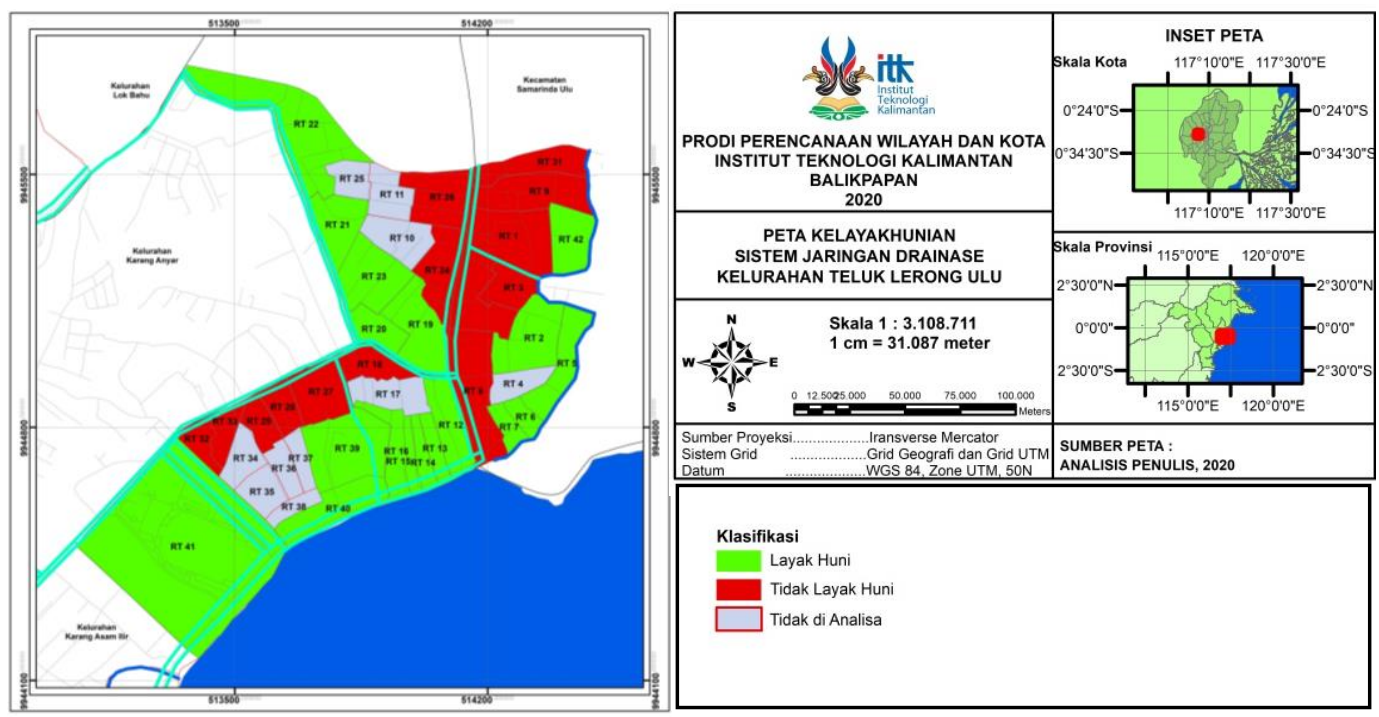

Gambar 4. Tingkat Layak Huni Kelurahan Teluk Lerong Ulu

\section{Kesimpulan}

Dari hasil analisis yang telah dilakukan, dapat disimpulkan bahwa standar tingkat layak huni Kecamatan Sungai Kunjang adalah 62,03\%. Dari total 197 RT, terdapat 117 RT memiliki kondisi saluran drainase yang layak huni dan sisanya sebanyak 80 RT memiliki kondisi saluran drainase yang tidak layak berdasarkan persepsi masyarakat. Variabel koordinasi dengan dinas terkait memiliki penilaian terendah. Karena dalam upaya perbaikan dan pemeliharaan saluran koordinasi pemerintah terkesan lambat dan kurang tanggap hingga menyebabkan banjir. Variabel karakteristik genangan air memiliki penilaian tertinggi. Padahal kondisi eksisting kejadian genangan di Kecamatan Sungai Kunjang tergolong cukup parah dengan tinggi genangan mecapai 50-80 cm dengan lama genangan 6-10 jam. Hal ini membuktikan bahwa masyarakat sudah pasrah dan tidak peduli dengan kondisi genangan.

\section{Referensi}

Deliana, Dea, Crhristiono Utomo. (2017). Tingkat Kepedulian pada Implementasi Sistem Drainase Sesuai dengan Zero Delta $Q$ dan Faktor Keberhasilannya pada Pengembangan Apartemen Di Surabaya. Jurnal Aplikasi Teknik Sipil : Volume 15, Nomor 2, Agustus 2017.

Elshater, Abeer, Hisyam G. Abussaada. (2016). The Unknown Cities. Africa: Patridge Publishing.

Fairizi, Dimitri. (2015). Analisis Dan Evaluasi Saluran Drainase Pada Kawasan Perumnas Talang Kelapa Di Subdas Lambidaro Kota Palembang. Jurnal Teknik Sipil dan Lingkungan : Vol.3, No.1, Maret 2015.

Helfira, Nany, Manyuk Fauzi, Ari Sandhyavitri. (2013). Identifikasi Parameter Dalam Penentuan Prioritas Penanganan Masalah Sistem Drainase Di Wilayah Kota Pekanbaru Menggunakan Metode Analytical Hierarcy Process (AHP).

Ikatan Ahli Perencanaan (IAP). (2017).Most Livable City Index. Jakarta: Ikatan Ahli Perencanaan.

Maizir. (2017). Evaluasi Kegagalan Pembangunan Drainase Dalam Lingkungan Daerah Pemukiman. Jurnal Teknik Sipil ITP : Vol. 4 No. 2 Juli 2017.

Makakalag, Andi, Piere H. Gosal, Poli Hanny. (2020). Kajian Kota Kotamobagu Menuju Kota Layak Huni (Liveable City). Jurnal Spasial Vol 6. No.2. Manado: Universitas Sam Ratulangi.

Peraturan Meteri Pekerjaan Umum Republik Indonesia Nomor 12 Tahun 2014 tentang Penyelenggaraan Sistem Drainase Perkotaan

Purwanto. (2016). Studi Pengendalian Banjir Sungai Loa Buah Kota Samarinda. Media Sains: Volume 9 Nomor 1.

Riman. (2011). Evaluasi Sistem Drainase Perkotaan Di Kawasan Kota Metropolis Surabaya. Widya Teknika : Vol.19 No.12; Oktober 2011.

Sen, Joy. (2013). Sustainable Urban Planning. New Delhi: TERI.

Sugiyono. (2013). Metode Penelitian Kuantitatif, Kualitatif dan R\&D. Bandung: Alfabeta. CV. 